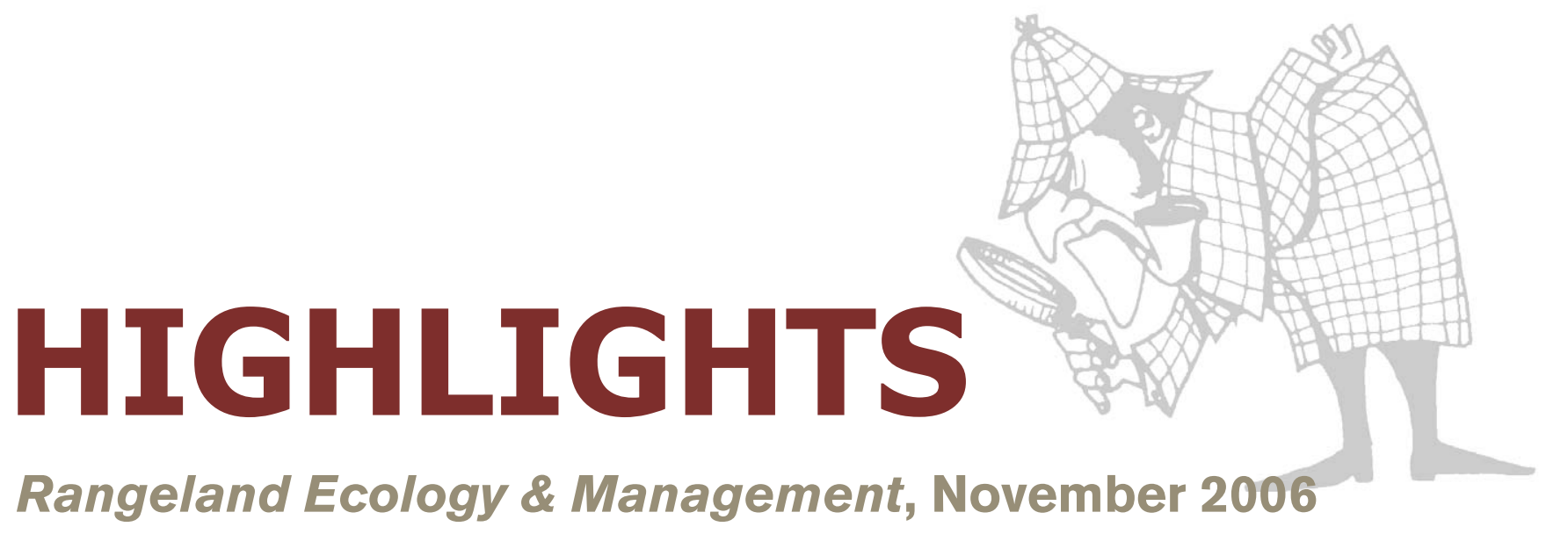

\section{Vegetation Characteristics Across Part of the Wyoming Big Sagebrush Alliance}

Kirk W. Davies, Jonathan D. Bates, and Richard F. Miller

The Wyoming big sagebrush alliance is the most extensive of the big sagebrush subspecies and provides critical habitat for many wildlife species and serves as a forage base for livestock production. This study describes cover potentials and defines distinct plant associations for relatively undisturbed Wyoming big sagebrush communities across part of its northwestern range. Vegetation cover and composition were highly variable among communities. However, variation in vegetation characteristics was reduced by forming plant associations based on dominant bunchgrass species. Comparing our results to the vegetation requirements proposed for sagegrouse suggest that the requirements exceed the ecological potential of many of the sites sampled.

\section{Strategic and Tactical Prediction of Forage Production in Northern Mixed-Grass Prairie}

Allan A. Andales, Justin D. Derner, Lajpat R. Ahuja, and Richard H. Hart

Stocking rates of livestock must be chosen based on the availability of forage. This study assessed the applicability of the GPFARM forage growth model for both long-term and within-season prediction of forage production in northern mixed-grass prairie in southeast Wyoming. The forage model explained $66 \%$ of the variability in peak standing crop from 1983 to 2001 whereas within-season forecasts ( 2 to 5 months lead time to peak biomass) explained $77 \%$ to $94 \%$ of biomass variability in 1983 . The model can provide site-specific strategic and tactical predictions of forage production that can help ranchers decide on an appropriate stocking rate.

\section{Long-Term Dynamics of Production, Respi- ration, and $\mathrm{Net} \mathrm{CO}_{2}$ Exchange in Two Sage- brush-Steppe Ecosystems}

Tagir G. Gilmanov, Tony J. Svejcar, Douglas A. Johnson, Raymond F. Angell, Nicanor Z. Saliendra, and Bruce K. Wylie
Sagebrush-steppe rangelands occupy vast areas in the US Intermountain West, but their significance for carbon budget and response to climate change had not previously been assessed quantitatively. We conducted long-term measurements of $\mathrm{CO}_{2}$ exchange in two sagebrush-steppe ecosystems in Idaho and Oregon and statistically analyzed the data, including partitioning $\mathrm{CO}_{2}$ flux into gross productivity and ecosystem respiration components. We established relationships of gross productivity and respiration to major environmental factors (radiation, temperature, precipitation), providing tools for quantitative analysis and prediction of the effects of climate change and management on productivity and carbon budget of this important category of rangeland resources.

\section{Long-Term Water Balance in a Semiarid Shrubland}

Bradford P. Wilcox, Steven L. Dowhower, W. Richard Teague, and Thomas L. Thurow

The density and coverage of mesquite shrublands in Texas and the Southwest have been increasing in the last 50-100 years. We know relatively little about the hydrology of these landscapes, especially in terms of how much runoff is generated at watershed scales. We monitored runoff and soil moisture from 9 small watersheds for more than a decade and found that runoff was a very small component of the water budget and only occurred during extraordinary storms. Most of the water was stored in the soil and evapotranspired. We believe there is little potential for increasing either surface runoff or groundwater recharge by removing mesquite shrubs.

\section{Grazing Management Effects on Sediment and Phosphorus in Surface Runoff}

Mathew M. Haan, James R. Russell, Wendy J. Powers, John L. Kovar, and Jamie L. Benning

Poor pasture management can increase sediment and phosphorus loading of surface water resources. Effects of pasture management on sediment and phosphorus losses in coolseason grass pastures were evaluated. Management practices included no grazing, spring hay harvest with fall stockpiled grazing, and summer grazing by continuous stocking or rota- 
tional stocking to 2 or 4 inches of residual forage. Phosphorus loss was greatest from pastures managed by continuous stocking and did not differ between the ungrazed, hay/stockpile, and rotational stocking to 4 inches of residual forage treatments. Negative impacts of grazing on surface water quality can be minimized by improved pasture management.

\section{Soil Erosion Thresholds and Alternative States in Northeastern Patagonian Range- lands}

\section{Marcelo P. Chartier and César M. Rostagno}

Long-term accelerated erosion may cause one stable community to cross a threshold to an alternative stable community. In 3 spatially related plant communities of northeastern Patagonia, we used rainfall simulation to determine interrill erosion. Sediment production and concentration were higher in the degraded shrub steppe than in the grass steppe. In the degraded grass steppe, the transitional state, a threshold in erosion was apparent as plant and litter cover decreased below $90 \%$. The importance of the erosion threshold concept when combined with a state-and-transition model is to depict the vegetation and soil changes on rangelands to anticipate persistent transitions in the future.

\section{Soil Nitrogen Availability in Tallgrass Prairie Under the Fire-Grazing Interaction \\ R. H. Anderson, Samuel D. Fuhlendorf, and David M. Engle}

Fire and grazing are interactive disturbance processes that are important to the structure and function of grassland ecosystems. We compared patches within a shifting mosaic landscape where each patch varied in time since focal disturbance (fire and intense grazing disturbance). Patterns of $\mathrm{N}$ availability were more similar to studies of grazing lawns where $\mathrm{N}$ availability is enhanced by focal grazing than to studies of fire without grazing. Fire-grazing interaction may provide a management alternative that enables sustainable livestock production through increased carrying capacity in focally disturbed patches, concomitant with biological diversity in tallgrass prairie.

\section{Property Rights Orientations and Rangeland Management Objectives: Texas, Utah, and Colorado}

Urs P. Kreuter, Malini V. Nair, Douglas Jackson-Smith, J. Richard Conner, and Janis E. Johnston

Management decisions affecting ecosystem services are likely mediated by landowners' views regarding their property rights. We conducted a mail survey to examine the extent to which rangeland owners in Texas, Utah, and Colorado would adopt management objectives that enhance ecosystem services. We found that willingness to adopt such objectives was positively correlated with respondents' social responsibility perspectives, and that Texas respondents were less willing to adopt them without compensation. This suggests that agencies promoting sustainable land management should foster social responsibility among landowners and that programs with this objective should account for differences in landowner dependence on private and public land.

\section{Grasshopper Abundance in an Arizona Rangeland Undergoing Exurban Development}

\section{Carl E. Bock, Zach F. Jones, and Jane H. Bock}

Exurban developments are replacing ranches in the West, but ecological impacts have been little studied. Grasshoppers are abundant herbivores that can have major ecological and economic significance. We compared grasshopper abundances in Arizona grasslands that were grazed by livestock, in exurban developments, or both, or neither. Densities were much higher on exurban properties where landowners kept livestock on small pastures than they were on nearby cattle ranches or on ungrazed areas. Results suggest that spatially heterogeneous and weedy vegetation associated with exurban pastures is more likely to support high densities of grasshoppers than is the relatively uniform vegetation associated with large ranches.

\section{Using Leaf Traits to Rank Native Grasses According to Their Nutritive Value}

Raouda Al Haj Khaled, Michel Duru, Virginie Decruyenaere, Claire Jouany, and Pablo Cruz

Little research has been done on the nutritive value of (semi)natural grasslands used for hay or grazing by domestic herbivores in spite of their recognized ecological interest. We proposed a new method based on the concept of plant functional traits to rank grass species according to digestible organic matter and chemical composition of the leaf. Leaf dry-matter content (LDMC), a leaf trait characterizing the ability of plant to capture and use resources, was better correlated with plant composition than previously established empirical indices. Measuring LDMC of grasses appears to be a promising tool to rank grassland communities according to their nutritive value.

\section{Grazing and Grazing Exclusion Effects on New Mexico Shortgrass Prairie} Jerry L. Holechek, Dee Galt, and Godfrey Khumalo

Information is needed on the effects of controlled livestock grazing and grazing exclusion on rangeland vegetation to better design grazing strategies for rangeland improvement. During the 6-year period from 1999 through 2004, there were no differences in vegetation basal cover, vegetation composition, or current year growth of perennial grasses between the conservative winter grazing or grazing exclusion areas of shortgrass prairie in northwestern New Mexico. Fluctuations did occur among years in response to precipitation. Our study 
indicates that long-term rest has no benefits to vegetation on blue grama (Bouteloua gracilis) rangelands.

\section{Improving Germination in Windmillgrass Ecotypes}

F. Herrera-C., W. R. Ocumpaugh, J.A. Ortega-S., J. Lloyd-Reilley, G. A. Rasmussen, and S. Maher

Hooded windmillgrass and shortspike windmillgrass seeds are often dormant, resulting in poor germination. Several seed treatments were evaluated, including whole seed, naked caryopsis, scarified naked caryopsis (30 seconds), scarified naked caryopsis (50 seconds), and scarified naked caryopsis (60 seconds). The greatest total germination $(P<0.05)$ was obtained with naked caryopsis for all studied ecotypes; the scarification treatments did not have a positive effect on this parameter. As scarification time increased the total germination decreased. These results allow seed analysts to know what specific dormancy is present in hooded and shortspike windmillgrasses and what method must be used to break it.

\section{Effect of Types of Biosolids and Cattle Manure on Desert Grass Growth}

Ricardo Mata-González, Ronald E. Sosebee, and Changgui Wan

There is limited information comparing the benefits of biosolids and manure to semiarid rangeland plant growth. We compared the effect of applying anaerobically produced biosolids, lime-stabilized biosolids, and cattle manure on the production of blue grama (Bouteloua gracilis) and black grama (Bouteloua eriopoda) grown in pots with moderate soil water content. All amendments produced similar increases in plant growth, despite their differences in plant nutrient concentrations, as a result of limitations in soil water. This information is important to associate the effect of biosolids application to that of the more conventional and socially accepted cattle manure application.
Influence of Plant Material Handling Protocols on Terpenoid Profiles of One-Seed Juniper Saplings

Santiago A. Utsumi, Andrés F. Cibils, Rick E. Estell, and Yuan-Feng Wang

Use of plant material with unaltered terpenoid profiles is of critical importance in controlled herbivory studies that involve junipers. Gas chromatography-mass spectrometry was used to compare the terpenoid profile of one-seed juniper leaves that were either refrigerated $\left(8^{\circ} \mathrm{C}\right)$ or frozen $\left(-80^{\circ} \mathrm{C}\right)$ for 3 weeks. Storage temperature was not associated with detectable differences in total terpenoid content; however, total terpenoid content and concentration of a few major compounds tended to decrease slightly under refrigeration. Refrigeration below $8^{\circ} \mathrm{C}$ for less than 3 weeks could prevent terpenoid profile alterations and facilitate herbivory studies involving one-seed juniper.

\section{Low-Cost Radiation Shielding for Use in Map- ping the Thermal Environments of Rangeland Animals \\ Patrick E. Clark, Douglas E. Johnson, Norman Harris, and David R. Thomas}

Mapping air temperature variations throughout a landscape may be helpful in predicting animal distribution patterns but intensive temperature sampling using commercial radiation shields is typically cost prohibitive. Two styles of shop-built radiation shields were constructed and tested as a low-cost and effective alternative to commercial shielding for air temperature mapping applications. Construction and deployment of either shielding style reduced the cost, time, and labor required to collect accurately and intensively sample air temperature throughout extensive and complex landscapes. This technology will aid researchers in gaining a better understanding of the role of local climate on range animal behavior. 